\title{
HYDRATION OF NATURAL GAS HYDROGEN MIXTURE TEST EQUIPMENT
}

\author{
Ildikó Bölkény \\ research assistant, University of Miskolc, Research Institute of Electronics and Informatics \\ 3515 Miskolc, Miskolc-Egyetemváros, e-mail: bolkeny@eiki.hu \\ Domonkos Horváth \\ student, University of Miskolc, Research Institute of Electronics and Informatics \\ 3515 Miskolc, Miskolc-Egyetemváros, e-mail: horvathdomi96@gmail.com \\ Marianna Vadászi \\ associate professor, University of Miskolc, Institute of Petroleum and Natural Gas \\ 3515 Miskolc, Miskolc-Egyetemváros, e-mail: vadaszi.marianna@uni-miskolc.hu
}

\begin{abstract}
The use of hydrogen as an energy source is advantageous because its combustion processes only produce water vapor, but not carbon dioxide. This excess energy can be stored in underground gas storage facilities, where it is delivered mixed with natural gas. In gas- and oil industry the formation of hydrate crystals can cause significant damages. A huge amount of hydrate crystal is formed, it can cause hydrate plugs in the pipeline. Like natural gas, hydrate formation occurs in the case of a natural gas-hydrogen mixture. The paper presents a method which can be used to study hydrate formation in natural gas-hydrogen mixture.
\end{abstract}

Keywords: gas hydrate, hydrogen, natural gas-hydrogen mixture, hydrate test

\section{Introducion}

Hydrogen, which occurs in large amounts on Earth in its compounds, is expected to be a promising energy carrier in the future. The use of hydrogen as an energy carrier has significant environmental benefits, as it promises a carbon-free energy supply (Stróbl, 2007). However, for hydrogen technology to spread, its problematic storage and transportation issues need to be addressed. In the storage and use of hydro-gen, the possibility has arisen that by mixing hydrogen with natural gas, using the existing natural gas pipeline storage facilities and networks, the blended mixture can reach the end users, thus achieving an increase in performance (Basniev et al., 2010).

In accordance with the above, it is therefore important to examine how the hydration of each hydrogen-natural gas mixture changes with natural gas. The formation of gas hydrate crystals can cause significant damage in the gas and oil industries. If a large amount of hydrate is formed, a hydrate plug may form in the pipeline. The hydrate plug causes a loss of production and results in a loss of money because removing the hydrate plug is a time consuming and expensive process.

The following is a summary of hydrate formation, a review of the literature on gas hydrate formation equipment, and a description of self-developed hydrate testing equipment and measurements.

The purpose of this paper is to present a hydrate test apparatus suitable for testing the hydration of different hydrogen-natural gas mixture concentrations. 


\section{The hydrate}

A gas hydrate is a solid state matter, as shown in Figure 1, which resembles snow or ice and consists of water and certain molecules of a so-called hydrate-forming gas. The hydrate-forming gas molecules are incorporated into the crystal lattice of $\mathrm{H}_{2} \mathrm{O}$, which is wider than ice, without chemical bonding. The primary causes of gas hydrate formation are that the gas must be at or below the water vapor dew point in the presence of free water, and that the gas temperature must be below the hydrate formation temperature for a given gas composition and gas pressure. In addition, secondary triggers or catalysts may be high flow rates, pressure pulsations, mixing with any external-internal effects, turbulence, or the presence of triggering solid particles that promote crystal formation. There are number of conditions for the formation and survival of a gas hydrate, such as the importance of having a sufficiently low temperature and high pressure in the system. It is important that the hydrate-forming gas be a covalent compound with molecular lengths less than $8 \times 10^{-10} \mathrm{~m}$ and not miscible with water in the liquid state. Of course, it is essential that liquid water be present in the system when the gas hydrate is formed (Bódi, 2003; Hammerschmidt, 1934).
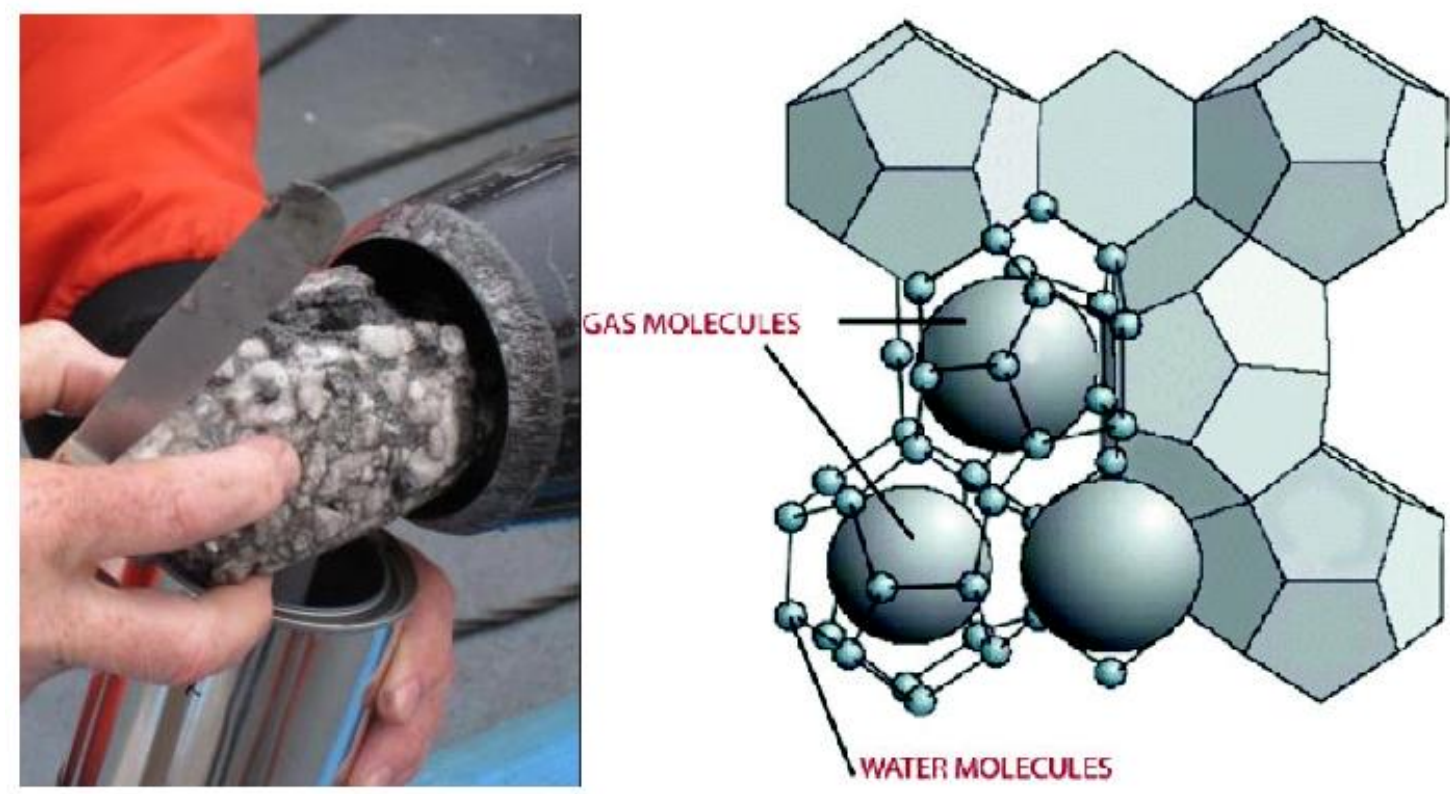

Figure 1. Gashydrate and structure (Wissen, 2020; Sharma et al., 2019)

Gas hydrates basically occur in three crystal structures, S1, S2, and SH. SH, i.e., the hexagonal type, was recently identified, while the other two were in the 1950s. The main structure of hydrates is water molecules, the gaps are filled with hydrocarbons. The S1 structure occurs in the natural environment, while the S2 structure is most common in oil fields. (Karamoddin and Varaminian, 2011; Sloan, 1998)

In the presence of hydrogen, it is involved in the formation of the hydrate from the beginning, both for Structure 1 and Structure 2, as illustrated in Figure 2. In the figure, the molecules ethane $\left(\mathrm{C}_{2} \mathrm{H}_{6}\right)$ are marked in red, methane $\left(\mathrm{CH}_{4}\right)$ in blue, and hydrogen $\left(\mathrm{H}_{2}\right)$ in green.

It is therefore important to examine the effect of hydrogen on hydrate formation. 


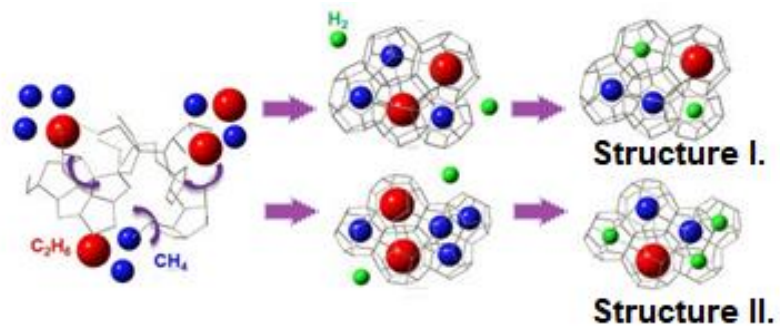

Figure 2. Gas phase hydrate formation (Ahn et al., 2020)

\section{The hydrate testing equipment}

Regarding the hydrate testing equipment, the formation of gas hydrates is examined at different research sites with different equipment and methods. We basically distinguish between static and dynamic equipment. Laboratory testing of gas hydrates is performed under static conditions at most research sites. Static hydrate testing equipment is basically used for hydrate formation, determination of thermodynamic equilibrium states, modelling and, to a lesser extent, determination of the effectiveness of hydrate inhibitors. These devices usually operate at atmospheric or low pressure. Using the results of the tests performed with static hydrate test devices, the first devices suitable for dynamic and quasidynamic tests were made. They are usually constructed by passing gases suitable for hydration, usually high-purity methane, carbon dioxide, or natural gas extracted from a natural real gas field, through a cell suitably designed for the experiment. The flow rate is usually designed according to the small sample and in most cases the pressure corresponding to the field is applied for the tests.

The equipment we created is a dynamic hydrate tester equipment for testing the hydration of a mixture of gas and hydrogen. An earlier piece of equipment from the University of Miskolc was considered in the design of the equipment. Accordingly, the metering device is a small sample test system corresponding to the gas flow and flow rate of domestic gas wells and the cross section of the wells. The internal pipe diameter of the system is $2 \mathrm{~mm}$, the tested pipe lengths are 6 and $12 \mathrm{~m}$, respectively. The flow values can be set in the range of 1-10 $\mathrm{nl} /$ min according to the modelling principles. With the model equipment simulating pipeline flows, tests can be performed in a temperature range like field conditions, $-20 \ldots+30^{\circ} \mathrm{C}$, under the pressure conditions used in the gas and oil industry, but at a maximum of 120 bar. (Bölkény et al., 2017; Bölkény and Füvesi, 2016)

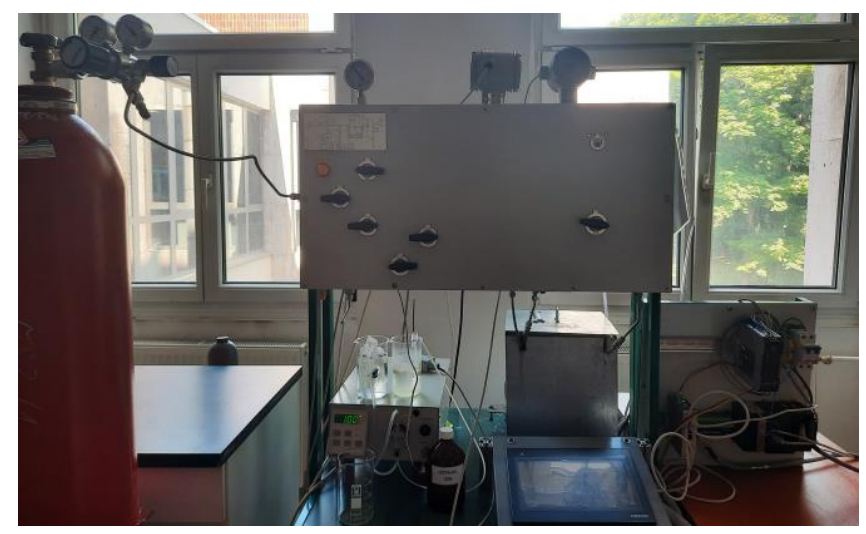

Figure 3. The hydrate testing equipment 
With the test equipment with the above parameters, the processes taking place in the pipe section from the well in the gas field to the collection station can be well modelled. On the gas supply side, a sample water mixture with a pre-set gas pressure and flow rate is required to be added to the formed test system, which can then be flowed through a test tube section placed in a set-temperature cool-ing unit. The cooling unit consists of a temperature-controlled liquid thermostat, a heat-insulated storage tank, cooling pipes and a temperature transmitter. Due to the flow resistance in the measuring tube section, a pressure difference can be measured at the measuring points, which significantly indicates the formation of a hydrate plug. Figure 4. shows the P\&I Diagram (Piping and Instrumentation Diagram) of the equipment, where PT-2 is pressure transmitter, PI-1 is pressure indicator, PT-2 and PT-3 are differential pressure transmitters, TT-5 is temperature transmitter, FT-6 is flow transmitter, GP-01 is gas tank, TC-01 is temperature control, TE-01 is temperature element, SZ-01..08 are hand valves, MV-01..02 are motor valves, SU-01 is pressure generator unit, SE-01 is separator cell.

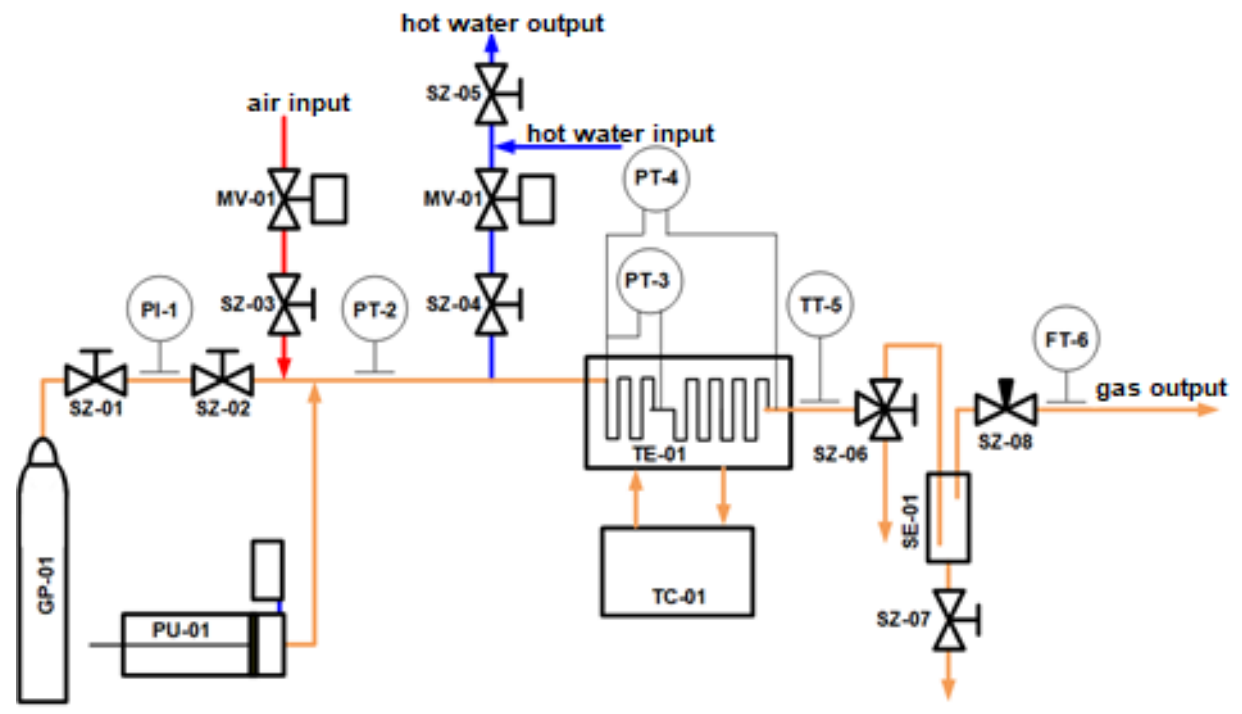

Figure 4. P\&I diagram of the hydrate testing equipment

Processes are monitored by an Omron PLC (Programmable Logic Controller) and HMI (Human Machine Interface). The signals of the differential pressure transmitters and the temperature transmitters are processed by the PLC, and the data are displayed and tabulated by the HMI. The data can be processed using a computer. Gas hydrate formation time was examined under gas well conditions ( $\mathrm{p}$, $\mathrm{dp}, \mathrm{T}, \mathrm{Q})$, with or without the addition of different inhibitors. The following parameters were recorded: pressure, differential pressure, temperature and flow rate.

The extracted natural gas consists of several components that can be separated during the purification process. Dry natural gas is a useful gas for us, which is mostly transported via pipelines. The other distinguished component is wet natural gas or gasoline, the valuable constituents of which are propane and butane. These are obtained by oil washing technology, which is filled into a mixture of PB, propane or butane bottles or containers after high-pressure liquefaction. The third distinct and important component is formation water, as the naturally formed reservoir rock contains water between its pores. Accordingly, during the measurements, it should be considered that in addition to the gas, stratified water and possibly gasoline must be added during the preparation of the gas sample. 


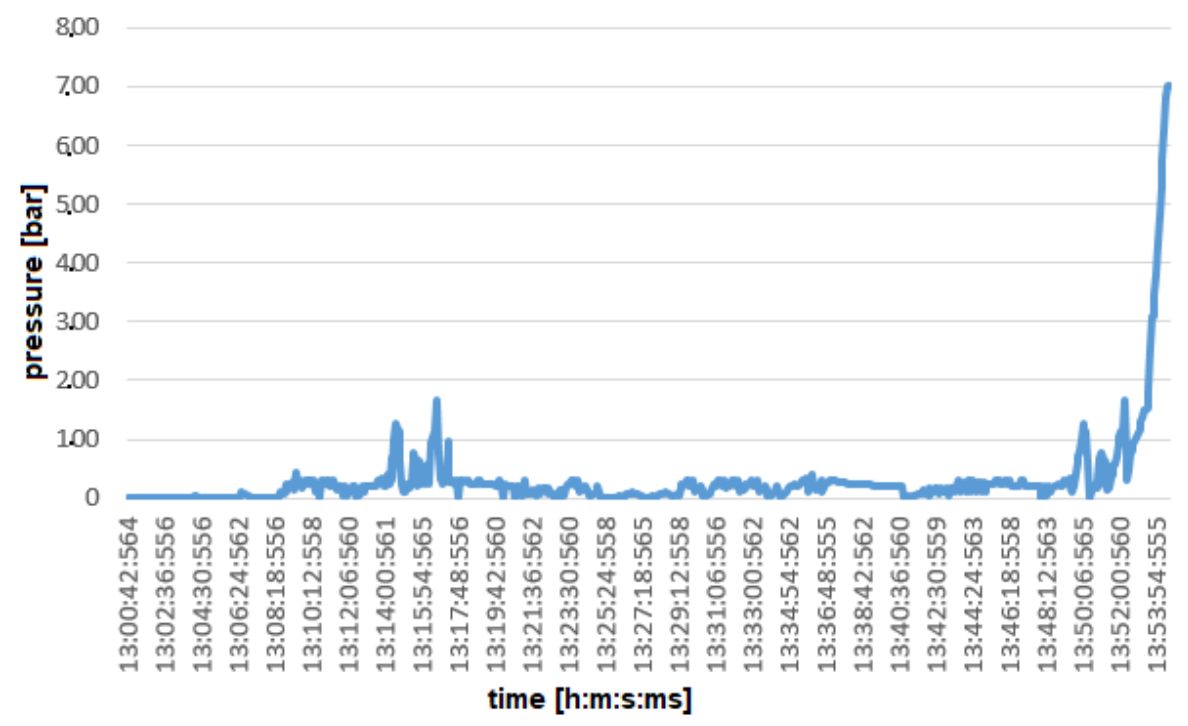

Figure 4. Measurement result

Test measurements were performed with the device using a $5 \mathrm{~V} / \mathrm{V} \%$ gas-hydrogen mixture. Figure 4 shows the result of one of the measurements. The formation of the hydrate can be seen from the change in pressure. Over time, the pressure change jumps and then reaches a maximum of 7 bar after a while. This clearly shows the formation of a hydrate plug. Compared to previous purely natural gas measurements, it is felt that the duration of hydrate formation is prolonged, if a small amount of hydrogen is mixed with the natural gas.

According to the plans, the measurements will be performed using a 5-10-15-20 V/V\% gas-hydrate mixture at different temperatures, pressures, and flow rates.

\section{Summary}

At the beginning of the article, the gas hydrate crystals causing significant dam-age in the gas and oil industry, the conditions of their formation and their basic properties were presented. Next, hydrate formation testing equipment has been described in the literature. In our study, we have discussed in detail the construction of a hydrate test apparatus suitable for studying the hydrate formation mechanism of a mixture of methane and hydrogen of different composition. Finally, we give a brief insight into an initial measurement result.

In the future, we intend to perform several measurements at different hydrogen concentrations (510-15-20). We also want to perform purely natural gas measurements. During the measurements we want to change the flow rate, the amount of water and the temperature.

\section{Acknowledgement}

The research was carried out at the University of Miskolc both as part of the „More efficient exploitation and use of subsurface resources" project implemented in the framework of the Thematic Excellence Program funded by the Ministry of Innovation and Technology of Hungary (Grant Contract reg. 
nr.: NKFIH-846-8/2019) and the project titled as „Developments aimed at increasing social benefits deriving from more efficient exploitation and utilization of domestic subsurface natural resources" supported by the Ministry of Innovation and Technology of Hungary from the National Research, Development and Innovation Fund in line with the Grant Contract issued by the National Research, Development and Innovation Office (Grant Contract reg. nr.: TKP-17-1/PALY-2020).

\section{References}

[1] Stróbl, A. (2007). Hidrogén az energiagazdálkodásban. Környezetvédelmi füzetek, 5. ELGOSCAR-2000 Környezettechnológiai és Vízgazdálkodási Kft., Budapest

[2] Basniev, K. S., Omelchenko, R. J., Adzynova, F. A.: Underground hydrogen storage problems in Russia, 2010 WHEC, Proceedings

[3] Bódi, T. (2003). Földalatti gáztárolás, gáztermelés. Miskolc

[4] Hammerschmidt, E. G. (1934). Formation of gas hydrates in natural gas transmission lines. Ind. Eng. Chem, 26(8), 851-855. https://doi.org/10.1021/ie50296a010

[5] Wissen. de SRE (2020). Gashydrate: Brennbares Eis als Gefahr oder Chance?

[6] Sharma, S., Saxena, A., Saxena, N. (2019). Introduction to gas hydrate. Unconventional Resources in India: The Way Ahead, 51-57. https://doi.org/10.1007/978-3-030-21414-2_9

[7] Karamoddin, M., Varaminian, F. (2011). Prediction of gas hydrate forming pressures by using $P R$ equation of state and different mixing rules

[8] Sloan, E. D. (1998). Clathrate hydrates of natural gases. Ch. 4-6, second edition, New York City: Marcel Dekker.

[9] Ahn, Y. H., Moon, S., Koh, D. Y., Hong, S., Lee, H., Lee, J. W., Park, Y. (2020). One-step formation of hydrogen clusters in clathrate hydrates stabilized via natural gas blending. Energy Storage Materials, 24(January), 655-661. https://doi.org/10.1016/j.ensm.2019.06.007

[10] Bölkény, I., Konyha, J., Füvesi, V., Szopkó, Sz.: Digital control algorithms in order to continous gas production, 2017 Tavaszi Szél, Tanulmánykötet. III. kötet., pp. 15-25. ISBN 978615-5586-18-7. https://doi.org/10.23715/TSZ.2017.3

[11] Bölkény, I., Füvesi, V.: Modelling and detection of gas hydrate appearance, 2016 ICCC, Proceedings of the 17th International Carpathian Control Conference, 835 p., 978-1-4673-8605-0 https://doi.org/10.1109/CarpathianCC.2016.7501072 